\title{
Ups and downs of African lakes
}

\section{Neil Roberts}

WHEREAS Quaternary climatic change in high latitudes is dominated by the buildup and decay of ice sheets, the dominant climatic signal in low-latitude regions is not glaciation but precipitation. In areas such as inter-tropical Africa, arid and humid phases have alternated as the monsoonal circulation system has been weakened and strengthened. Tropical palaeoclimate is recorded most clearly by changes in the water level and chemistry of 'non-outlet' lakes. These had low water levels, indicating an arid climate, during and after the last glacial maximum (21$12.5 \mathrm{kyr}$ ago), followed by a period of high lake levels (a humid climate) during the early part of the present interglacial (12.5 $-5 \mathrm{kyr}$ ago). Unlike the slow responses of glaciation and vegetation to high-latitude climatic change, many low- and midlatitude lakes respond rapidly to hydroclimatic change. On page 141 of this issue', Gasse et al. present high-resolution stratigraphic records spanning the period from 15 to $7 \mathrm{kyr}$ ago from two such 'responsive' lake basins, one on each side of the Sahara. These two records show that, like the eustatic sea-level record of Northern Hemisphere deglaciation ${ }^{2}$, the last arid-to-humid transition in Africa was not smooth, being broken by climatic events lasting $100-1,000$ years.

Major climate changes driven by the Milankovitch cycle of the Earth's orbital variations are well established. SubMilankovitch climatic oscillations (known traditionally as stadials and interstadials) superimposed on these longer-term astronomically induced variations have also long been recognized, but they are currently becoming of increased palaeoenvironmental interest ${ }^{3}$.

Their causes remain a subject of debate, but these almost certainly include agencies such as major emissions of volcanic dust and the formation of North Atlantic deep water ${ }^{3 .+}$. Of these palaeoclimatic oscillations, the so-called Younger Dryas event (11-10 kyr ago) has received the greatest attention. Evidence now suggests that this event was felt well beyond its place of origin in northwest Europe, although its manifestation varied regionally across the globe ${ }^{\text {s.t. }}$.

In inter-tropical Africa, the period of the Younger Dryas is marked by sharp regressions in the water level of lakes such as Bosumtwi (Ghana, $\left.6^{\circ} \mathrm{N}\right)$, Chad $\left(13^{\circ} \mathrm{N}\right)$ and Ziway-Shala (Ethiopia, $8^{\circ} \mathrm{N}$ ), indicating negative hydrological balances (a net deficit of water) and an arid climate These same lakes also record later regressional (arid) events of apparently similar magnitude and duration to the one contemporaneous with the Younger Dryas,

for example between 8.0 and $7.2 \mathrm{kyr}$ ago. This 7.5 -kyr event is broadly coincident with, and may have been caused by, the collapse of the Laurentide ice sheet over Hudson's Bay. Although ${ }^{1+} \mathrm{C}$ chronologies indicate that the hydro-climatic events centred on 10.2 and $7.5 \mathrm{kyr}$ ago were synchronous between different lake basins in Africa, they have seemed until recently to be geographically restricted to sites in the inter-tropical zone. But the investigation by Gasse et al. of the more

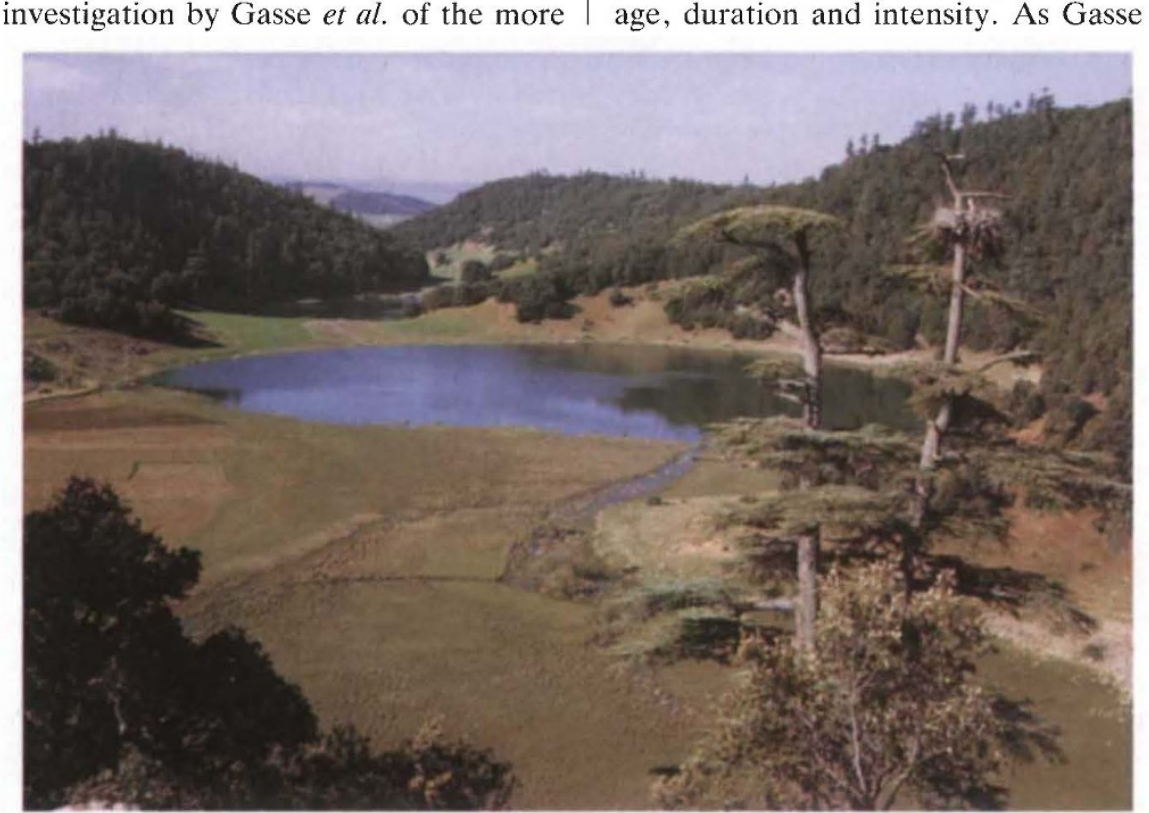

ling natural from cultural factors. Nonetheless, data are beginning to emerge which suggest that tropical climatic 'crises' occurred not simply over recent millennia but even in recent centuries. One especially startling piece of evidence comes from cores taken in Lake Malawi, which reveal that the level of this great lake fell by about $100 \mathrm{~m}$ at some stage within the past thousand years, signifying a reduction in rainfall at that time to $50-70$ per cent of modern values ${ }^{10}$

To understand the climatic mechanisms responsible for these hydro-climatic events, there is a need to establish as precisely as possible their spatial extent, age, duration and intensity. As Gasse et

Lake Tigalmamine, in the Middle Atlas mountains of Morocco. Pollen and diatom analyses of sediment cores ${ }^{8.9}$ from this lake show evidence of abrupt short-term falls in lake level which occurred at times similar to those known from sites in tropical Africa.

northerly Sebkha Mellala lake basin (Algeria, $\left.32^{\circ} \mathrm{N}\right)$, and similar studies on the Tigalmamine basin (Morocco, $33^{\circ} \mathrm{N}$ ) (refs 8 and 9 , and $\mathrm{H}$. Lamb et al., unpublished work), now reveal that these short-lived regressional events occurred beyond as well as within the tropics. The interruptions to the hydrological cycle at around 10.2 and $7.5 \mathrm{kyr}$ ago are thus apparently of continental or even of global significance

One intriguing question, on which the jury is still out, is whether subMilankovitch climatic events have occurred throughout the recent geological past or whether they were restricted to times of major climatic transition, such as the end of the last glaciation. Abrupt lake-level oscillations are not equally "visible' throughout the late Quaternary record: regressional events, for example, are stratigraphically much more evident at times of high rather than low lake levels. The record of the late Holocene (in any case a period of low lake levels in Africa) is complicated further by increasing human influence and the difficulty of disentang- al. have shown, non-outlet lakes in regions such as Africa and the western United States look set to provide the best source of answers to such questions. It is clear that, unlike the Milankovitch changes brought about by variations in the solar radiation received by the Earth, these events cannot easily be predicted, thereby creating considerable uncertainty for projections of future climate.

Neil Roberts is in the Department of Geography, Loughborough University of Technology, Loughborough, Leicestershire LE11 3TU, UK.

1. Gasse, F., Téhet, R., Durand, A., Gibert, E. \& Fontes, J.-C Nature 346, 141-146 (1989).

2. Fairbanks, R.G. Nature 342, 637-642 (1989).

3. Berger, A. \& Labeyrie, W.H. (eds) Abrupt Climatic Changes, Evidence and Implications (Reidel, Dordrecht, 1987).

4. Street-Perrott, F.A. \& Perrott, R.A. Nature 343, 607-612 (1990)

5. Harvey, L.D.D. Quat. Sci. Rev. 8, 137-149 (1989).

6. Roberts, N. et al. Quat. Newsl. 3, 1-5 (1981).

7. Street-Perrott, F.A. \& Roberts, N. in Variations in the Global Water Budget (eds Street-Perrott, F.A. et al.) 331-345 (Reidel, Dordrecht, 1983)

8. Lamb, H.F. et al. J. Biogeogr. 16, 65-74 (1989)

9. El Hamouti, N. thesis, Universite de Paris-Sud (1989)

10. Owen, R.B. et al. Proc. R. Soc. Lond. B 240, 519-553 (1990) 